\title{
Effect of Calcium on Structure, Phase Composition and Hardening of Al-Zn-Mg Alloys Containing up to 12wt.\%Zn
}

\author{
Nikolay Aleksandrovich Belov ${ }^{a}$, Evgenia Alexandrovna Naumova ${ }^{b}$, Torgom Karoevich Akopyan ${ }^{a *}$ \\ ${ }^{a}$ National University of Science and Technology-MISIS, 4, Leninskiy Prospect, Moscow, 119049, Russia \\ ${ }^{b}$ Bauman Moscow State Technical University, 5, ul. Baumanskaya 2-ya, Moscow, 105005, Russia
}

Received: September 11, 2015; Revised: October 7, 2015

\begin{abstract}
The influence of calcium on structure and phase composition of the aluminum alloys, containing additions of zinc up to $12 \mathrm{wt} . \%$ and magnesium ( $3.5 \mathrm{wt} . \%$ ) was studied. The increase of $\mathrm{Zn}$ content leads to formation of $\mathrm{Al}_{4} \mathrm{Ca}$ primary crystals at lower concentrations of calcium. Zinc is distributed between aluminum solid solution and intermetalic phases (Ca-containing and $\mathrm{T}-\mathrm{Al}_{2} \mathrm{Mg}_{2} \mathrm{Zn}_{3}$ ) in the alloys of the $\mathrm{Al}-\mathrm{Zn}-\mathrm{Mg}-\mathrm{Ca}$ system. The eutectic $(\mathrm{Al})+\mathrm{Al}_{4} \mathrm{Ca}$ has fine structure and particles of $\mathrm{Al}_{4} \mathrm{Ca}$ are capable to spheroidization during heat treatment at $500^{\circ} \mathrm{C}$. The maximal level of hardness observed on calcium containing alloys was higher than $200 \mathrm{HB}$, what gives a reason to expect good strength properties. Due to summarized results it is seen that the Al-Zn-Mg-Ca system is promising for development of new eutectic type high-strength aluminum alloys.
\end{abstract}

Keywords: high-strength aluminum alloys, phase composition, phase diagrams, thermodynamic calculations, castings, structure

\section{Introduction}

AA7005 type aluminum alloys based on the Al-Zn-Mg system with sum content of zinc and magnesium in between 4-7 wt. \% are widely used due to good combination of their technological and service properties ${ }^{1,2}$. These alloys are characterized by intermediate strength, high ductility, good level of welding properties and good resistance to corrosion. However, the increase of the content of alloying elements leads to corrosion cracking. Thus high strength aluminum alloys were developed on the base of the Al- $\mathrm{Zn}-\mathrm{Mg}-\mathrm{Cu}$ system (AA7075, 7055, 7085 etc.), where the summed content of zinc, magnesium and copper achieves 12-13 wt.\% $(\mathrm{Zn}+\mathrm{Mg} \text { up to } 10 \mathrm{wt} . \%)^{1-10}$. Due to the high strength of the alloys (UTS up to 700-750 MPa) these alloys are of especial interest and are used in different fields ${ }^{1}$. However, because of the small amounts of the eutectic, alloys of the 7xxx type has very low casting properties (in particular hot tearing). For this reason the usage of these alloys for production of complicated castings is difficult, although several attempts were made ${ }^{11}$.

An addition of eutectic forming elements (in particular $\mathrm{Ni}$ ) could be used to improve casting properties of $7 \mathrm{xxx}$ type alloys as it was reported in works ${ }^{11-18}$. Aluminum alloys containing $(\mathrm{Al})+\mathrm{Al}_{3} \mathrm{Ni}$ eutectic and aluminum matrix with $\mathrm{Mg}+\mathrm{Zn}$ up to $10 \%$ allows to achieve the unique combination of mechanical and technological properties, what was observed on experimental alloys. The alloy Al-7\%Zn-3\%Mg-4\% Ni ${ }^{15-18}$ should be marked out from this group of alloys. This material has strength of the same level as AA7075 but its casting properties are much better, what allows the production of shaped castings.

*e-mail: nemiroffandtor@yandex.ru
However, high price of nickel, its relatively small world resources ${ }^{1}$ and high demand for this element for production of super alloys prevents wide use of this component for aluminum alloys. Thus examination of other eutectic forming elements, which give similar effect to structure as nickel, but do not have above mentioned minuses, is reasonable.

We believe that one of the most promising elements among them is calcium that, similar to nickel, forms with aluminum a diagram of eutectic type. According to the data ${ }^{2}$, in the Al-Ca system the $\mathrm{L} \rightarrow(\mathrm{Al})+\mathrm{Al}_{4} \mathrm{Ca}$ eutectic reaction takes place at $7.6 \% \mathrm{Ca}$ and $617^{\circ} \mathrm{C}$, which is rather close to the calculated values obtained in the Thermo-Calc software application (Figure 1). In terms of abundance in nature, calcium holds the $3^{\text {rd }}$ place among all the metals (about $3.4 \mathrm{wt} \%$ ), behind aluminium and iron ${ }^{1}$, and its density is lower than that of silicon $\left(1.542\right.$ versus $\left.2.328 \mathrm{~g} / \mathrm{sm}^{3}\right)$. In recent years, many publications considering calcium-containing magnesium alloys have appeared ${ }^{19-21}$. At the same time, the use of calcium for alloying of aluminium alloys is very limited ${ }^{20-23}$. As a rule, this element is considered to be a harmful impurity. Several attempts to develop alloys based on Al-Ca system (in particular those with increased zinc content), which were characterized with tendency to superplasticity were carried during $70^{\text {th }}-80^{\text {th }}$ of the previous century ${ }^{19,20}$. Despite positive results these works were not continued. There is no literature data covering possibility of using $\mathrm{Ca}$ as alloying element for casting aluminum alloys, although structure of the Al-Ca phase diagram (Figure 1) gives promising predictions.

Limited amount of experimental data could be found in the literature for the Al-Ca-Zn ternary system (phase diagram of quaternary $\mathrm{Al}-\mathrm{Ca}-\mathrm{Mg}-\mathrm{Zn}$ system is unknown). Kono et al. ${ }^{22}$ studied the system using micrography, inverse rate thermal analysis, X-ray diffraction and EPMA analysis. 
Later, Prince ${ }^{23}$ assessed the system based on the work of Kono et al. According to ${ }^{23}$ aluminum solid solution may be in equilibrium with $\mathrm{Al}_{2} \mathrm{CaZn}_{2}$ and $\mathrm{Al}_{13} \mathrm{Ca}$.

The main target of the present work was to study the influence of $\mathrm{Ca}$ on structure, phase composition and as a result, mechanical properties of the Al-Zn-Mg alloys. Selected compositions of the alloys were providing essential effect of age hardening.

\section{Experimental Procedure}

Aluminum-based alloys of the Al-Zn-Mg-Ca system with constant content of $\mathrm{Mg}(3.5 \mathrm{wt} \%)$ were the objects of the study (Table 1). Most of the alloys had content of zinc varying from 6 to 12 wt.\%, what corresponds to the concentration field where the effect of age hardening is maximal ${ }^{9}$. Ternary alloy $\mathrm{Al}-3.5 \% \mathrm{Mg}-12 \% \mathrm{Zn}$ has its position close to maximal

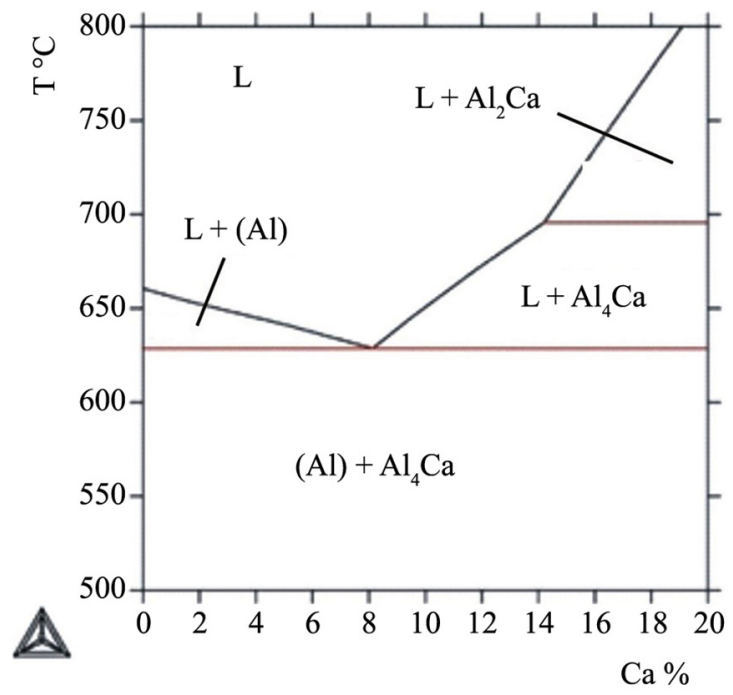

Figure 1. Binary Al-Ca eutectic. solid solubility of magnesium and zinc in aluminum solid solution in accordance with Al-Mg-Zn phase diagram ${ }^{2}$. Experimental alloys were prepared in an electric furnace in graphite-chamotte crucibles using $99.99 \%$ pure Al, 99.9\% pure $\mathrm{Mg}$, 99.9\% pure $\mathrm{Zn}$ and $99.8 \%$ metallic calcium. Pieces of calcium were inputted into capsules made of aluminum foil and dipped under surface of the melt and kept there until complete dissolution in the melt in order to prevent the burning of calcium. Melting and casting temperatures were in the range of $720-740^{\circ} \mathrm{C}$. Alloys were cast in graphite molds with internal dimensions of $15 \times 30 \times 180 \mathrm{~mm}$; the cooling rate $\left(\mathrm{V}_{\mathrm{c}}\right)$ was about $10 \mathrm{~K} \mathrm{~s}^{-1}$. Chemical analysis of selected samples showed the deviation from the nominal concentrations of $\mathrm{Zn}$ and $\mathrm{Mg}$ to be less than 5\%. Binary alloys with compositions close to eutectic point (Al) $+\mathrm{Al}_{4} \mathrm{Ca}$ were prepared for additional control of deviation from nominal concentration of $\mathrm{Ca}$. Microstructures of the following alloys were analyzed: A1-7.2\% Ca, Al-7.6\% Ca and $\mathrm{Al}-8.0 \% \mathrm{Ca}$. Alloys had hypoeutectic, eutectic and hypereutectic structure correspondingly, what is in accordance with a phase diagram reported in the reference ${ }^{2}$. These alloys were taken as standards for chemical analysis of $\mathrm{Ca}$. An annealing of the samples was carried in the electrical furnace "Nabetherm" in the air atmosphere. The temperature gradient inside the furnace was $2 \mathrm{~K}$. Ageing of samples was carried in drying oven with forced air movement.

The structure was examined in optical (OM, Neophot-30) and scanning electron (SEM, TESCAN VEGA 3) microscopes and by electron microprobe analysis (EMPA, OXFORD AZtec). Polished samples cut from the central part of the ingots were objects of studying. Mechanical polishing (Struers Labopol-5) was used as well as electrolytic polishing, as these methods complement one another and enable the complete observation of the microstructure. Electrolytic polishing was made using $12 \mathrm{VDC}$ in electrolyte containing 6 parts of ethyl alcohol, 1 part of $\mathrm{HClO} 4$ and 1 part of glycerin.

For the thermal analysis a differential scanning calorimeter Seteram Labsys DSC-16 was used; heating and cooling curves were recorded at a rate of $\sim 0.08 \mathrm{~K} \mathrm{~s}^{-1}$. Archimedes

Table 1. Chemical compositions of aluminum-based alloys of the Al-Zn-Mg-Ca system.

\begin{tabular}{|c|c|c|c|c|c|c|c|c|c|}
\hline \multirow{2}{*}{ No } & \multicolumn{4}{|c|}{ Concentrations ${ }^{1}, w^{\circ} \%$} & \multirow{2}{*}{ No } & \multicolumn{4}{|c|}{ Concentrations $^{1}$, wt $\%$} \\
\hline & $\mathbf{Z n}$ & $\mathrm{Ca}$ & Mg & Al & & $\mathbf{Z n}$ & $\mathrm{Ca}$ & Mg & Al \\
\hline 1 & - & - & 3.42 & Balance & 12 & 8.87 & 0.53 & 3.28 & Balance \\
\hline 2 & - & 3.85 & 3.41 & Balance & 13 & 9.13 & 1.04 & 3.36 & Balance \\
\hline 3 & - & 5.44 & 3.33 & Balance & 14 & 9.21 & 1.99 & 3.52 & Balance \\
\hline 4 & - & 6.54 & 3.35 & Balance & 15 & 9.12 & 2.87 & 3.63 & Balance \\
\hline 5 & - & 7.25 & 3.44 & Balance & 16 & 8.84 & 3.85 & 3.55 & Balance \\
\hline 6 & 5.88 & - & 3.54 & Balance & 17 & 8.95 & 4.55 & 3.47 & Balance \\
\hline 7 & 6.25 & 1.04 & 3.46 & Balance & 18 & 11.07 & 2.94 & 3.51 & Balance \\
\hline 8 & 6.14 & 1.87 & 3.32 & Balance & 19 & 11.74 & - & 3.45 & Balance \\
\hline 9 & 5.89 & 2.97 & 3.46 & Balance & 20 & 12.45 & 1.85 & 3.47 & Balance \\
\hline 10 & 5.93 & - & 3.64 & Balance & 21 & 11.73 & 2.28 & 3.34 & Balance \\
\hline 11 & 5.98 & 0.25 & 3.39 & Balance & 22 & 12.34 & 4.05 & 3.64 & Balance \\
\hline \multicolumn{10}{|c|}{ Reference alloy 7055} \\
\hline & Zn & & & $\mathrm{Cu}$ & $\mathbf{Z r}$ & & $\mathrm{Fe}$ & $\mathbf{S i}$ & Al \\
\hline & 7.95 & & & 2.44 & 0.12 & & 0.08 & 0.05 & Balance \\
\hline
\end{tabular}


method was applied for the determination of density of the samples. The commercial alloy AA7055 was used as a standard material for comparison. Brinell hardness test (HB) was used to evaluate hardening of the alloys after heat treatment (load $2500 \mathrm{MPa}$, indenter diameter $5 \mathrm{~mm}$ and load time $30 \mathrm{~s}$ ).

Calculations of phase equilibria were carried out with the use of Thermo-Calc software (database TTAL5) ${ }^{24,25}$.

\section{Results and Discussion}

Experimental alloys were selected based on the carried out calculations of the phase composition using Thermo-Calc (Figures 2a, b). An increase of the zinc concentration leads to formation of the primary $\mathrm{Al}_{4} \mathrm{Ca}$ crystals at lower concentrations of Ca (monovariant curve a-b of $L \rightarrow(\mathrm{Al})+\mathrm{Al}_{4}$ Ca reaction). Position of this line is in accordance with experimental data (Figure 2c). In particular faced primary crystals could be easily observed in the structure of the alloy Al- $12 \% \mathrm{Zn}-4 \% \mathrm{Ca}-3.5 \% \mathrm{Mg}$ (Figure $3 \mathrm{a}$ ). The as-casts structure of hypoeutectic alloys

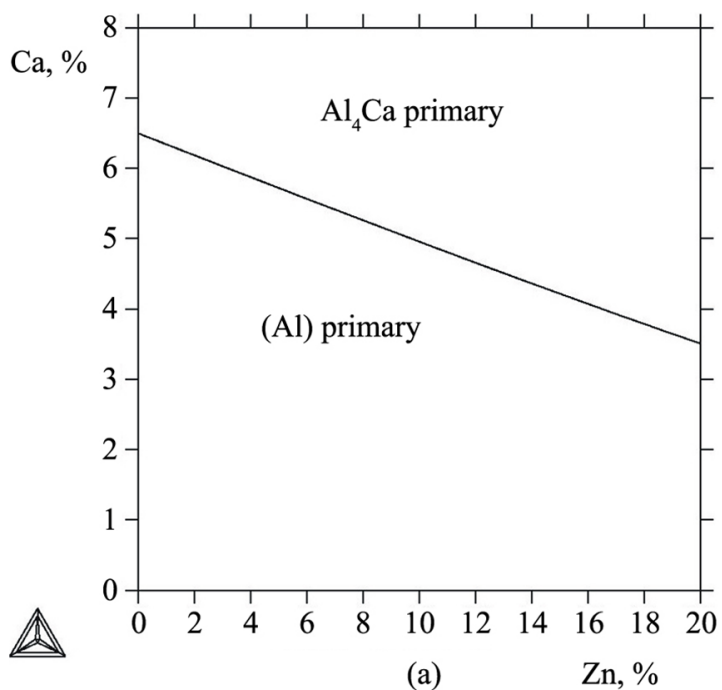

consists of primary crystals of the aluminum solid solution, which have morphology of dendrite cells, eutectic colonies (Al) $+\mathrm{Al}_{4} \mathrm{Ca}$ and veins of non-equilibrium eutectic, which mostly consist of $\mathrm{Al}_{2} \mathrm{Mg}_{3} \mathrm{Zn}_{3}$ phase, and rarely of $\mathrm{MgZn}_{2}$ (Figure $3 \mathrm{~b}$ ). The structure of the $\mathrm{Al}-9 \% \mathrm{Zn}-4 \% \mathrm{Ca}-3.5 \% \mathrm{Mg}$ alloy was mostly eutectic with fine morphology of Ca-containing phase (Figure 3c).

The eutectic alloys, where the morphology of intermetallic phases is globular have the best combination of mechanical properties $^{11-17}$. For this reason one of the main targets of studying of the Ca containing alloys is to determine the tendency of the $\mathrm{Al}_{4} \mathrm{Ca}$ phase to spheriodization as well as peculiarities of this process during heat treatments. Two-step heating was used for the annealing: $450{ }^{\circ} \mathrm{C}, 3 \mathrm{~h}+500{ }^{\circ} \mathrm{C}, 3 \mathrm{~h}$. After the annealing the alloys were quenched (in the cold water). Dissolution of the non-equilibrium eutectic was the main process running during the first stage of the annealing while globular particles of $\mathrm{Al}_{4} \mathrm{Ca}$ were formed during the second stage. Thus, the favorable microstructure which

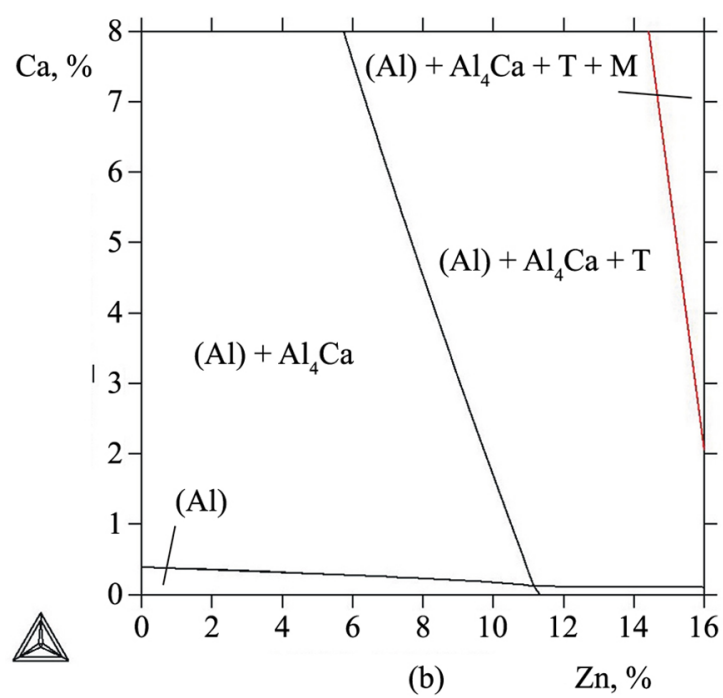

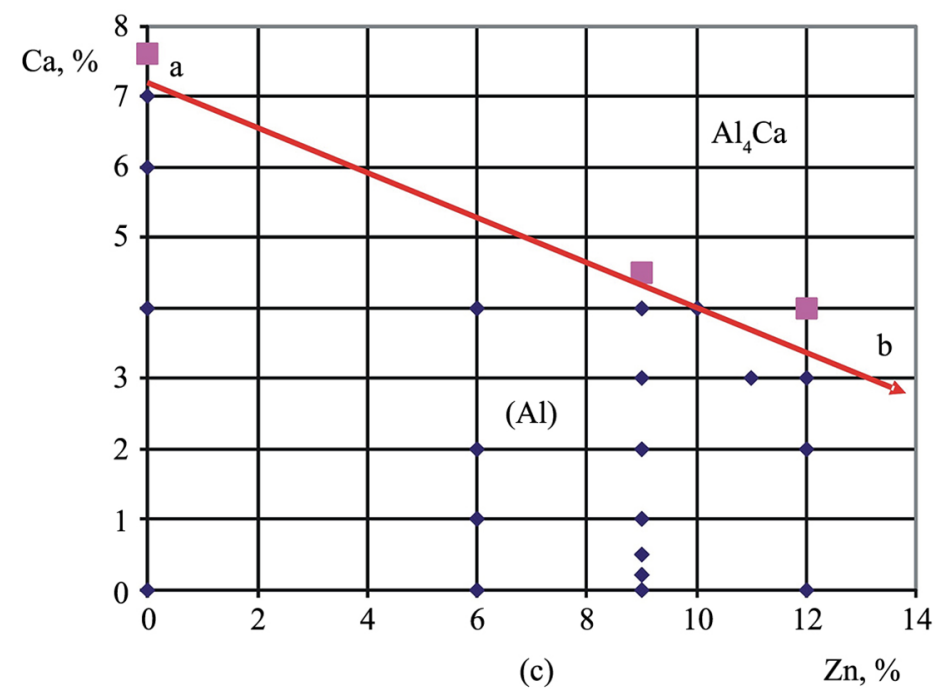

Figure 2. Liquidus (a) and solidus (b) projections and compositions of experimental alloys (c) of the Al-3.5\%Mg-Zn-Ca section. 


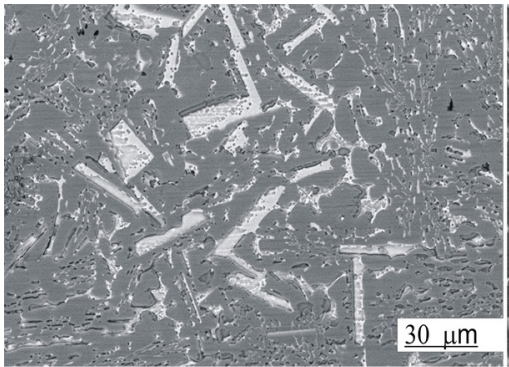

(a)

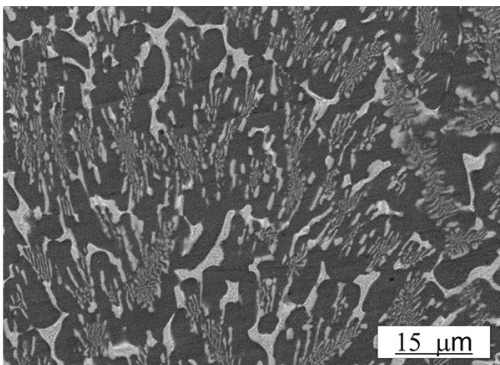

(b)

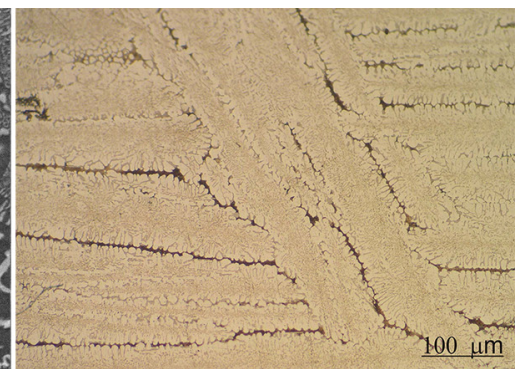

(c)

Figure 3. Microstructures of the alloys Al-3.5\%Mg-Zn-Ca in as-cast state: (a) $12 \% \mathrm{Zn}$ and $4 \% \mathrm{Ca}$; (b) $11 \% \mathrm{Zn}$ and $3 \% \mathrm{Ca}$; (c) $9 \% \mathrm{Zn}$ and $4 \% \mathrm{Ca}$. (a, b) SEM; (c) OM.

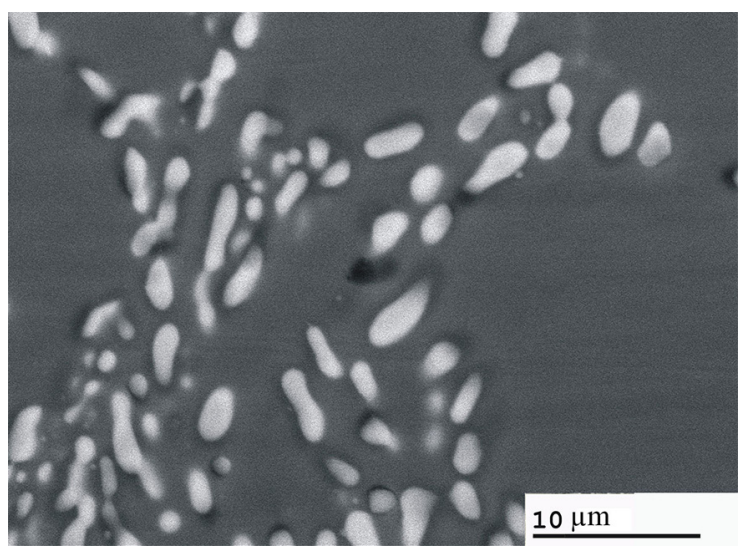

Figure 4. Microstructure of the alloy Al-11\% $\mathrm{Zn}-3 \% \mathrm{Ca}-3.5 \% \mathrm{Mg}$ in as-quenched state $\left(500^{\circ} \mathrm{C}\right)$, SEM.

forms during the annealing in the alloys with large fraction of eutectic is a result of the sperodization process, that was observed during the experiment (Figure 4).

Zinc enters in relatively large amounts in the $\mathrm{Ca}$-containing phases (particularly in ternary compound: $\mathrm{Al}_{3} \mathrm{ZnCa}$ according to $^{22}$ or $\mathrm{Al}_{2} \mathrm{CaZn}_{2}$ according to ${ }^{23}$ ). For this reason it's essential to determine distribution of zinc between intermetallic phase and aluminum solid solution (Al). EMPA analysis was applied in order to experimental obtain composition of primary crystals and eutectic intermetallic phases of the alloys. EMPA results for the Al-9\% $\mathrm{Zn}-3 \% \mathrm{Ca}-3.5 \% \mathrm{Mg}$ alloy in as-quenched state (see in Figure $5 \mathrm{~b}$ and Table 2) showed that only $\sim 4 \%$ of $\mathrm{Zn}$ remains in aluminum solid solution, what is two times less in comparison to the alloy without $\mathrm{Ca}$ (the solid solution composition for the alloys without $\mathrm{Ca}$ (6, 10 and 19 in Table 1$)$ is equal to the alloy composition (after quenching)).

So, the elements distribution (the proposed variant see in Table 3) should be taken into account for selection of optimal composition.

Essential information about influence of $\mathrm{Ca}$ and temperature on phase composition of the alloys could be obtained from analysis of vertical sections. Calculated vertical section plotted for the constant content of $9 \% \mathrm{Zn}$ is presented on Figure 6. Calculated results (Figure 6) are in accordance with thermal (Figure 7) and structure (OM, SEM, EMPA) analysis (Figures 2-5). Using the Sheil model ${ }^{24-26}$ of the non- equilibrium solidus temperature was calculated and presented in Figure 6. Additions of $\mathrm{Ca}$ lead to decrease of liquidus temperature (maximal decrease is for $26^{\circ} \mathrm{C}$ ), while nonequilibrium solidus temperature is changing insignificantly. Thus the solidification interval is decreasing what supposes improvement of casting properties ${ }^{11}$. The DSC results for the Al-9\% $\mathrm{Zn}-3.5 \% \mathrm{Mg}-1 \% \mathrm{Ca}$ alloy showed the increase of equilibrium and non-equilibrium solidus (Tns in Figure 6) in comparison with the calculated data, what could be explained by decrease of $\mathrm{Zn}$ concentration in aluminum solid solution. It should be noted that TTAL5 database ${ }^{27}$ describes $\mathrm{Al}_{4} \mathrm{Ca}$ phase as a binary compaund and solubility of $\mathrm{Zn}$ in this phase is not taken into account. Ternary compounds (AlCaZn) are absent in this database. Thus, a possibility to optimize composition of the alloy using calculations is limited and so requires additional experimental investigations.

In accordance with above mentioned analysis alloys with concentrations of Ca close to the monovariant line $\mathrm{a}-\mathrm{b}$ (Figure 2c) have most favorable microstructures, which consist of matrix based on aluminum solid solution of the Al-Zn-Mg system and globular particles of the $\mathrm{Al}_{4} \mathrm{Ca}$ phase. Hardness tests were carried on quenched alloys after ageing at room temperature for 7 days (T4) and after ageing at $130{ }^{\circ} \mathrm{C}, 20 \mathrm{~h}$ (T6). Conditions of the ageing were chosen in accordance with data obtained for the Al-Zn-Mg-Ni system ${ }^{15,16}$.

The level of maximal obtained hardness for experimental alloys was higher than 200HB (Table 4), what is similar for the data obtained for the alloys of the AA7075/7055 type (The hardness of wrought alloy 7055 in casting after T6 treatment is $195 \mathrm{HB})$. The influence of calcium on hardness depends from concentration of $\mathrm{Zn}$ : when concentration of zinc is $6 \%$, the addition of $\mathrm{Ca}$ leads to decrease of hardness, however, the hardness is not changing when concentration of $\mathrm{Zn}$ is $9-12 \%$ (Table 4). This effect could be observed on Figure 8 , where the influence of addition of $4 \% \mathrm{Ca}$ on the results of hardness tests is shown. The high level of hardness was observed in a wide range of concentrations of $\mathrm{Zn}$ and $\mathrm{Ca}$ (Table 4), what gives enough wide field for the optimization of the composition of the alloys.

Between other positive effects it must be noted that addition of calcium prevents the formation of T-phase $\left(\mathrm{Al}_{2} \mathrm{Mg}_{3} \mathrm{Zn}_{3}\right)$ at grain boundaries and leads to the decrease of density of the alloy. The first effect is especially important for homogenized ingots. To achieve most unfavorable conditions, the selected alloys were annealed at $500{ }^{\circ} \mathrm{C}$ 
and then cooled in the furnace. The alloys which were not alloyed with calcium had long chains of $\mathrm{T}\left(\mathrm{Al}_{2} \mathrm{Mg}_{3} \mathrm{Zn} \mathrm{n}_{3}\right)$ phase along the grain borders (Figure 9a). Evidently such type of structure is not satisfactory for work treatment (extruding, rolling, forging, etc.), as such chains lead to the formation of microcracks which leads to formation of brittle intergranual fracture. These chains appear in alloys with small addition of $\mathrm{Ca}$ (Figure 9b). However, no chains were observed in alloys

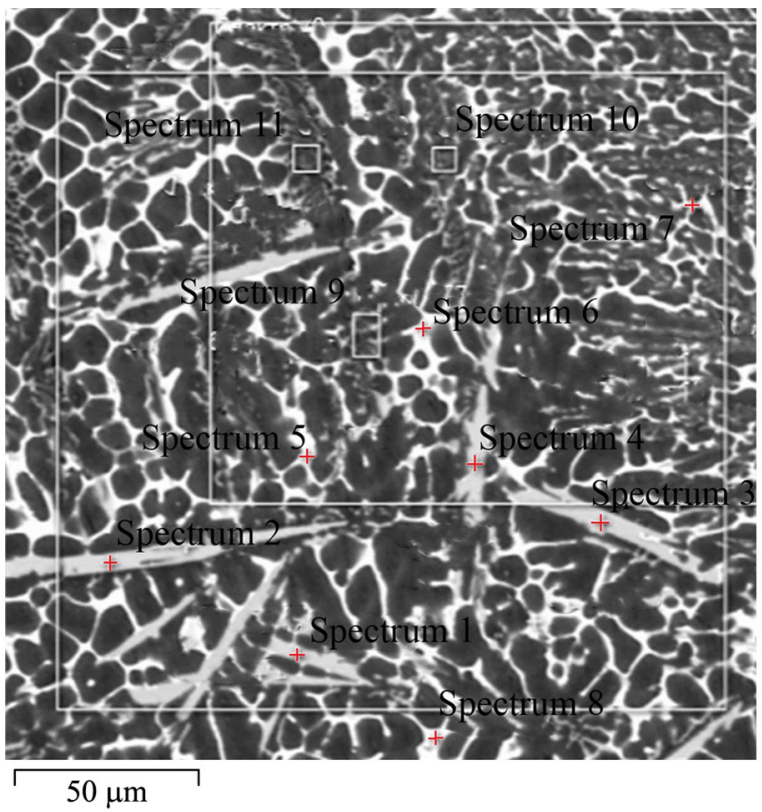

(a)

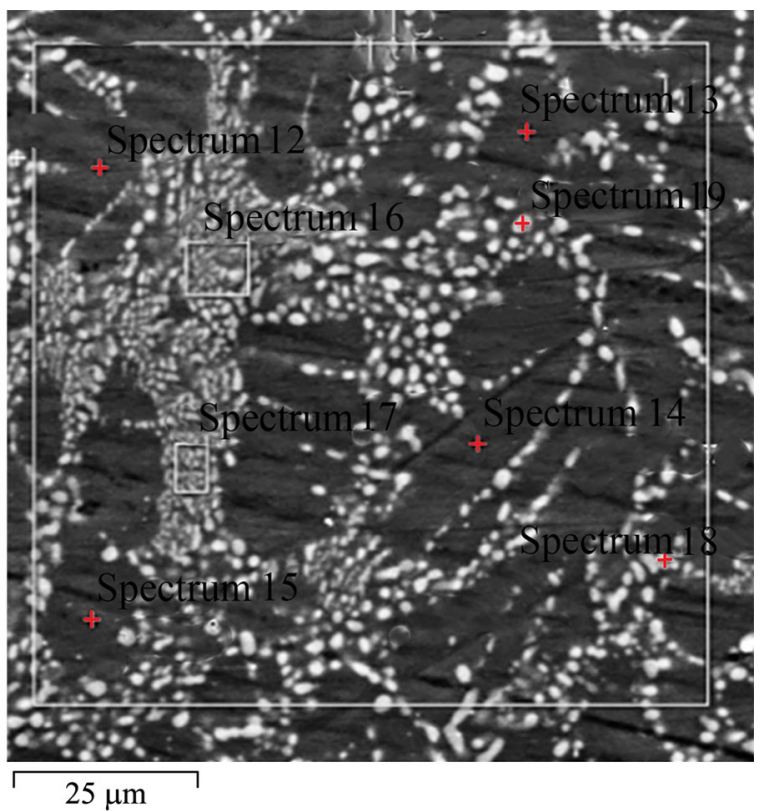

(b)

Figure 5. Results of energy-dispersive $\mathrm{X}$-ray spectroscopy (a) Al-12\% Zn- $4 \% \mathrm{Ca}-3.5 \% \mathrm{Mg}$ alloy in as-cast state; (b) $\mathrm{Al}-9 \% \mathrm{Zn}-3 \% \mathrm{Ca}-3.5 \% \mathrm{Mg}$ alloy in as-quenched state $\left(500^{\circ} \mathrm{C}\right), \mathrm{SEM} / \mathrm{EMPA}$.

Table 2. The results of EMPA (see Figure 5).

\begin{tabular}{|c|c|c|c|c|c|}
\hline \multirow{2}{*}{ Number of spector } & \multicolumn{4}{|c|}{ Concentrations, wt $\%$} & \multirow{2}{*}{ Phase identification } \\
\hline & Mg & Al & $\mathbf{C a}$ & $\mathbf{Z n}$ & \\
\hline 1 & 0.38 & 42.91 & 20.74 & 35.97 & Primary $\mathrm{Al}_{4} \mathrm{Ca}$ \\
\hline 2 & 0.57 & 42.74 & 20.91 & 35.78 & Primary $\mathrm{Al}_{4} \mathrm{Ca}$ \\
\hline 3 & 0.94 & 43.58 & 19.69 & 35.79 & Primary $\mathrm{Al}_{4} \mathrm{Ca}$ \\
\hline 4 & 0.25 & 43.8 & 17.8 & 37.29 & Primary $\mathrm{Al}_{4} \mathrm{Ca}$ \\
\hline 5 & 11.91 & 26.58 & 0.03 & 61.48 & $\begin{array}{c}\mathrm{Al}_{2} \mathrm{Mg}_{3} \mathrm{Zn}_{3} \\
\text { eutectic }\end{array}$ \\
\hline 6 & 8.96 & 29.83 & 1.11 & 59.96 & $\begin{array}{c}\mathrm{Al}_{2} \mathrm{Mg}_{3} \mathrm{Zn}_{3} \\
\text { eutectic }\end{array}$ \\
\hline 7 & 6.99 & 34.43 & 1.02 & 56.9 & $\begin{array}{c}\mathrm{Al}_{2} \mathrm{Mg}_{3} \mathrm{Zn}_{3} \\
\text { eutectic }\end{array}$ \\
\hline 8 & 6.76 & 43.37 & 1.73 & 48.08 & $\begin{array}{c}\mathrm{Al}_{2} \mathrm{Mg}_{3} \mathrm{Zn}_{3} \\
\text { eutectic }\end{array}$ \\
\hline 9 & 0.68 & 78.13 & 3.49 & 17.54 & Eutectic \\
\hline 10 & 1.08 & 75.86 & 3.39 & 19.64 & Eutectic \\
\hline 11 & 0.8 & 75.33 & 3.98 & 19.73 & Eutectic \\
\hline 12 & 4.74 & 90.34 & 0.09 & 4.66 & (Al) \\
\hline 13 & 1.86 & 94 & 0.23 & 3.73 & $(\mathrm{Al})$ \\
\hline 14 & 2.09 & 93.98 & 0 & 3.91 & $(\mathrm{Al})$ \\
\hline 15 & 1.35 & 94.89 & 0.08 & 3.54 & (Al) \\
\hline 16 & 2.15 & 80.58 & 6.61 & 10.51 & Eutectic \\
\hline 17 & 2.29 & 78.47 & 7.17 & 11.94 & Eutectic \\
\hline 18 & 2.13 & 79.14 & 6.99 & 11.61 & Eutectic \\
\hline 19 & 4.7 & 76.76 & 5.73 & 12.72 & Eutectic \\
\hline
\end{tabular}




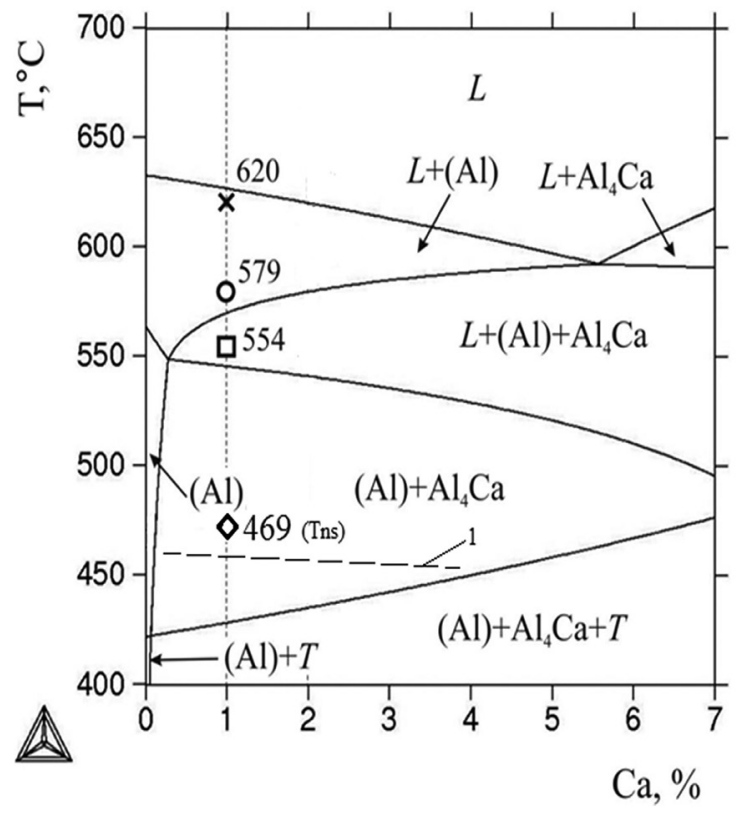

Figure 6. Calculated vertical section $\mathrm{Al}-3.5 \% \mathrm{Mg}-9 \% \mathrm{Zn}-\mathrm{Ca}$ and experimental data from DSC analysis ( 1 - calculated non-equilibrium solidus).

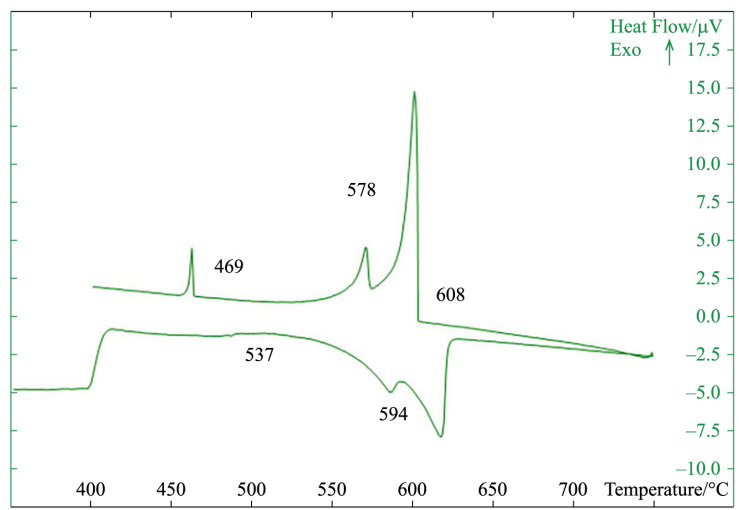

Figure 7. DSC-curves of the alloy Al-9\% $\mathrm{Zn}-3.5 \% \mathrm{Mg}-1 \% \mathrm{Ca}$.

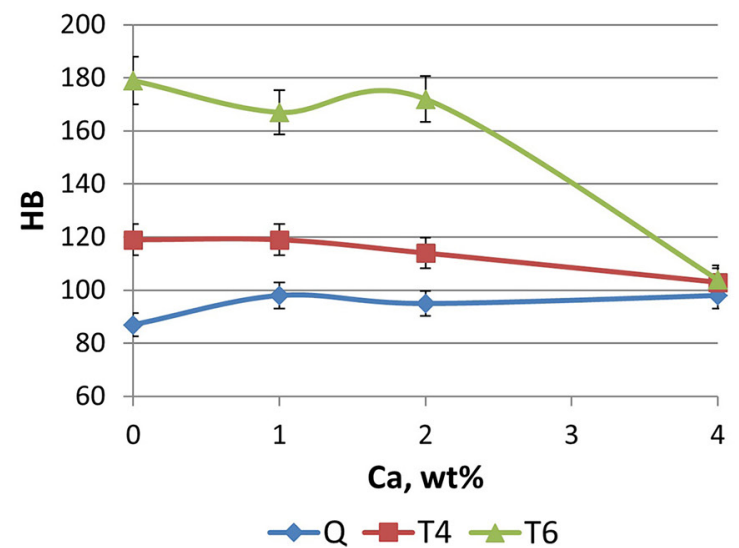

(a) with concentration of $\mathrm{Ca}$ higher than $2 \%$. Microstructures of these alloys were similar to those in as-quenched state (Figure 4). Due to the fact that calcium has lower density than aluminum it was evident that its effect on density of the alloy will be positive. Density of experimental alloy

Table 3. Possible distribution of elements between the phases in alloys of the Al-Ca-Zn-Mg system in Al-corner ${ }^{2,12,22,23}$.

\begin{tabular}{ccccc}
\hline & Al & Zn & Mg & Ca \\
\hline Precipitates & & & & \\
$\mathrm{T}^{1}$ & + & + & + & - \\
$\mathrm{M}^{1}$ & $+-^{2}$ & + & + & -
\end{tabular}

Eutectic and primary phases

$\begin{array}{cc}\mathrm{T}^{1} & + \\ \mathrm{M}^{1} & +- \\ \mathrm{Al}_{2} \mathrm{CaZn} & + \\ \mathrm{Al}_{4} \mathrm{Ca} & + \\ \mathrm{CaZn}_{13} & -\end{array}$

${ }^{1} \mathrm{~T}: \mathrm{Al}_{2} \mathrm{Mg}_{3} \mathrm{Zn}_{3} ; \mathrm{M}: \mathrm{MgZn}_{2} .{ }^{2 *+}+$ " and "--" symbols indicate the presence or absence of elements in the phases.

Table 4. Influence of zinc and calcium on hardness (HB) of the alloys $\mathrm{Al}-3.5 \% \mathrm{Mg}-\mathrm{Zn}-\mathrm{Ca}$ in different states ${ }^{1}$.

\begin{tabular}{cccrcr}
\hline \multirow{2}{*}{ No } & \multicolumn{2}{c}{ Content, wt.\% } & \multicolumn{3}{c}{ HB } \\
\cline { 2 - 6 } & Zn & Ca & Q & T4 & \multicolumn{1}{c}{ T6 } \\
\hline 1 & 0 & 0 & $57 \pm 2$ & $58 \pm 1$ & $57 \pm 2$ \\
2 & 0 & 4 & $82 \pm 2$ & $84 \pm 3$ & $84 \pm 2$ \\
3 & 6 & 0 & $87 \pm 3$ & $119 \pm 2$ & $179 \pm 1$ \\
4 & 6 & 1 & $98 \pm 3$ & $119 \pm 2$ & $167 \pm 4$ \\
5 & 6 & 2 & $95 \pm 4$ & $114 \pm 4$ & $172 \pm 3$ \\
6 & 6 & 4 & $98 \pm 3$ & $103 \pm 3$ & $104 \pm 5$ \\
7 & 12 & 0 & $124 \pm 2$ & $157 \pm 5$ & $201 \pm 4$ \\
8 & 12 & 2 & $138 \pm 4$ & $165 \pm 5$ & $211 \pm 4$ \\
9 & 12 & 3 & $139 \pm 5$ & $164 \pm 4$ & $219 \pm 5$ \\
10 & 12 & 4 & $138 \pm 5$ & $159 \pm 4$ & $215 \pm 5$ \\
\hline
\end{tabular}

${ }^{1} \mathrm{Q}$ : quenched; T4: aged at ambient temperature (7 days); T6: aged at $130^{\circ} \mathrm{C}, 20 \mathrm{~h}$.

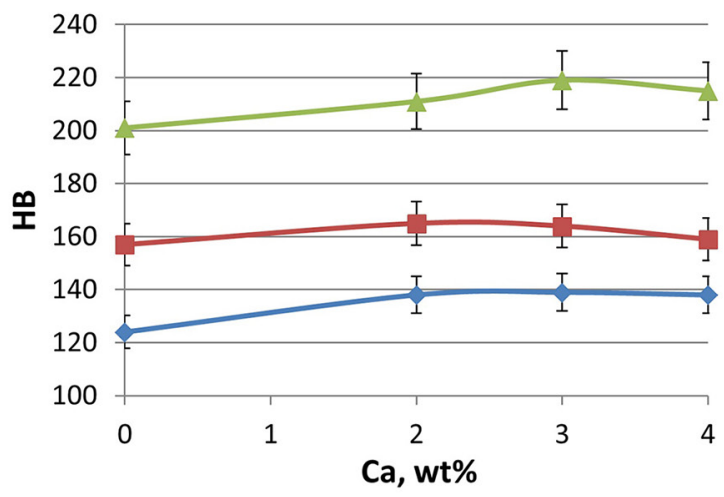

(b)

Figure 8. Influence of $\mathrm{Ca}$ on hardness for the alloys with different zinc content: (a) $6 \% \mathrm{Zn}$; (b) $12 \% \mathrm{Zn}$. 


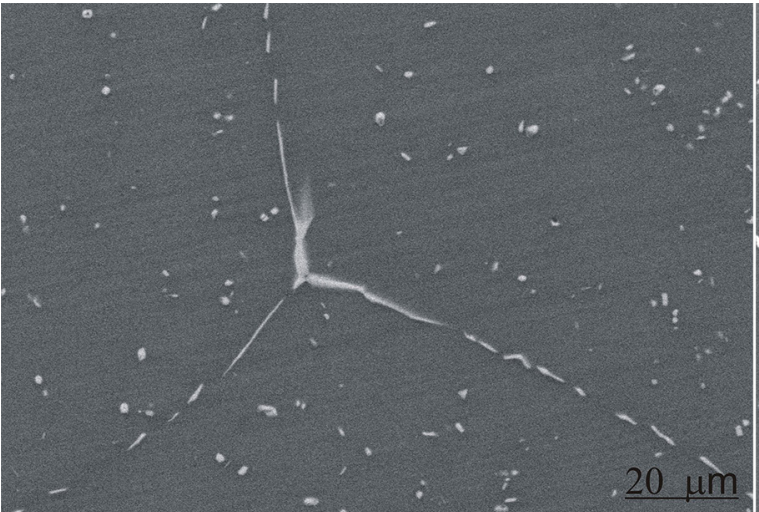

(a)

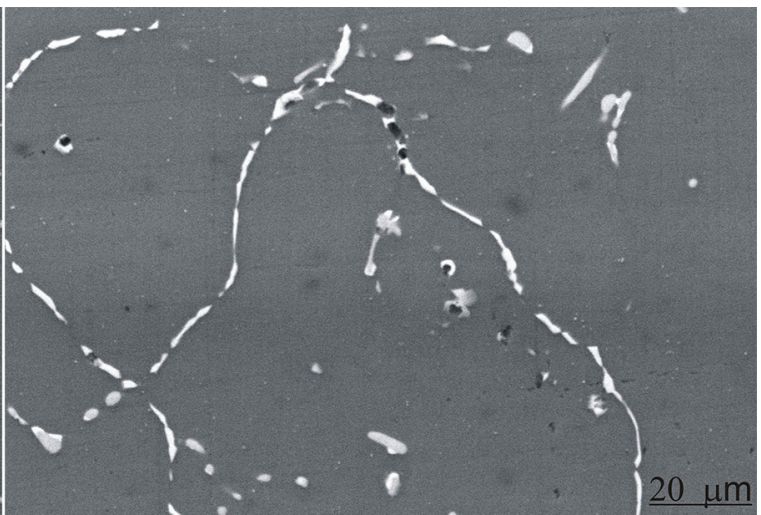

(b)

Figure 9. Annealed microstructures of Al-9\%Zn-3.5\%Mg (a) and Al-9\%Zn-3.5\%Mg- $0.5 \% \mathrm{Ca}$; (b) alloys after slow cooling $\left(\mathrm{Vc} \sim 0,1 \mathrm{~K} \mathrm{~s}{ }^{-1}\right)$.

Al-9\%Zn-4\%Ca-3.5\%Mg appeared to be essentially lower $\left(2.676 \mathrm{~g} / \mathrm{cm}^{3}\right)$ than that of the commercial alloys AA7075 $\left(\sim 2.8 \mathrm{~g} / \mathrm{cm}^{3}\right)$. It was also noted that during heat treatment the surface of the alloys containing calcium was not darkening. Thus, the properties of oxide surface of aluminum alloys are improved.

Due to above mentioned results it is seen that Al-Zn-Mg-Ca system is promising for development of new eutectic type high-strength aluminum alloys.

\section{Conclusions}

The influence of calcium on structure and phase composition of the aluminum alloys, containing additions of zinc up to $12 \mathrm{wt} \%$ and magnesium $(3.5 \mathrm{wt} \%)$ was studied. It was found that the increase of $\mathrm{Zn}$ content leads to formation of $\mathrm{Al}_{4} \mathrm{Ca}$ primary crystals at lower concentrations of calcium. When zinc content is $12 \%$, the phase boundary corresponds to $3.5 \% \mathrm{Ca}$. Zinc is distributed between aluminum solid solution and intermetalic phases (Ca-containing and $\mathrm{T}-\mathrm{Al}_{2} \mathrm{Mg}_{3} \mathrm{Zn}_{3}$ ) in the alloys of the Al-Zn-Mg-Ca system. So,

\section{References}

1. Polmear IJ. Light metals: from traditional alloys to nanocrystals. 4rd ed. Oxford: Elsevier/Butterworth-Heinemann; 2006.

2. Davis JR. Aluminum and aluminum alloys. Ohio: ASM; 1993. ASM Specialty Handbook.

3. Marlaud T, Deschamps A, Bley F, Lefebvre W and Baroux B. Evolution of precipitate microstructures during the retrogression and re-ageing heat treatment of an $\mathrm{Al}-\mathrm{Zn}-\mathrm{Mg}-\mathrm{Cu}$ alloy. Acta Materialia. 2010; 58(14):4814-4826. http://dx.doi.org/10.1016/j. actamat.2010.05.017.

4. Marlaud T, Deschamps A, Bley F, Lefebvre W and Baroux B. An Influence of alloy composition and heat treatment on precipitate composition in Al-Zn-Mg-Cu alloys. Acta Materialia. 2010; 58(1):248-260. http://dx.doi.org/10.1016/j.actamat.2009.09.003.

5. Du ZW, Sun ZM, Shao BL, Zhou TT and Chen CQ. Quantitative evaluation of precipitates in an $\mathrm{Al}-\mathrm{Zn}-\mathrm{Mg}-\mathrm{Cu}$ alloy after isothermal aging. Materials Characterization. 2006; 56(2):121-128. http:// dx.doi.org/10.1016/j.matchar.2005.10.004.

6. Chen J, Zhen L, Yang S, Shao W and Dai S. Investigation of precipitation behavior and related hardening in AA 7055 zinc distribution should be taken into account for selection of optimal composition.

The eutectic $(\mathrm{Al})+\mathrm{Al}_{4} \mathrm{Ca}$ has dispersed structure and particles of $\mathrm{Al} 4 \mathrm{Ca}$ are capable to spheroidization during the heat treatment at $500{ }^{\circ} \mathrm{C}$. Such microstructure may provide the best combination of mechanical properties (particularly strength and ductility). The maximal level of hardness observed on calcium containing alloys was higher than $200 \mathrm{HB}$, what gives the reason to expect good strength properties too.

Presence of Ca-containing eutectic particles prevents formation of intergranular chains of the $\mathrm{Al}_{2} \mathrm{Mg}_{3} \mathrm{Zn}_{3}$ phase during cooling at relatively low rates, what is good for the deforming treatment of ingots.

\section{Acknowledgements}

The authors wish to acknowledge the financial support from Russian Scientific Foundation (project number 14-19-00632).

aluminum alloy. Materials Science and Engineering. 2009; 500:34-42.

7. Desmukh MN, Pandey RK and Mukhopadhyay AK. Fatigue behavior of 7010 aluminum alloy containing scandium. Scripta Materialia. 2005; 52(7):645-650. http://dx.doi.org/10.1016/j. scriptamat.2004.11.018.

8. Li J-F, Peng Z-W, Li C-X, Jia Z-G, Chen W-J and Zheng Z-Q. Mechanical properties, corrosion behaviors and microstructures of 7075 aluminium alloy with various aging treatments. Transactions of Nonferrous Metals Society of China. 2008; 18(4):755-762. http://dx.doi.org/10.1016/S1003-6326(08)60130-2.

9. Senkov ON, Shagiev MR, Senkova SV and Miracle DB. Precipitation of Al3(Sc,Zr) particles in an Al-Zn-Mg-Cu-Sc-Zr alloy during conventional solution heat treatment and its effect on tensile properties. Acta Materialia. 2008; 56(15):3723-3738. http://dx.doi.org/10.1016/j.actamat.2008.04.005.

10. Li Y, Li P, Zhao G, Liu X, Cui J. The constituents in Al$10 \mathrm{Zn}-2.5 \mathrm{Mg}-2.5 \mathrm{Cu}$ aluminum alloy. Materials Science and Engineering. 2005; 397:204-208.

11. Zolotorevskiy VS, Belov NA and Glazoff MV. Casting aluminum alloys. Amsterdam: Elsevier; 2007. p. 539. 
12. Belov NA, Aksenov AA and Eskin DG. Multicomponent phase diagrams: applications for commercial aluminum alloys. Amsterdam: Elsevier; 2005.

13. Belov NA and Zolotorevskij VS. The effect of nickel on the structure, mechanical and casting properties of aluminium alloy of 7075 type. In: Proceedings of the 8th International Conference on Al-Alloys and Their Physical and Mechanical Properties (ICAA8); 2002; Cambridge, UK. Dürnten: Trans Tech Publications; 2002. p. 935-940.

14. Axenov AA, Belov NA and Zolotorevskij VS. Aluminum-based material and a method for manufacturing products from aluminumbased material. US Patent 6.585.932 B1. 2003 July 1.

15. Belov NA and Zolotorevskii VS. Casting alloys on the base of aluminum-nickel eutectic (nikalines) as possible alternative to silumins. TsvetnyeMetally. 2003; 2:99-105.

16. Belov NA, Cheverikin VV, Eskin DG and Turchin AN. Effect of $\mathrm{Al} 3 \mathrm{Ni}$ and $\mathrm{Mg} 2 \mathrm{Si}$ eutectic phases on casting properties and hardening of an $\mathrm{Al}-7 \% \mathrm{Zn}-3 \% \mathrm{Mg}$ alloy. In: Proceedings of the 10th Internatinal Conference on Al-Alloys (ICAA10); 2006; Vancouver, CA. Dürnten: Trans Tech Publications; 2006. p. 413-418.

17. Belov NA, Zolotorevskij VS and Cheverikin VV. Aluminumbased material. RU Patent 2245388. 2005 Jan 27.

18. Belov NA. Quantitative phase analysis of the Al- $\mathrm{Zn}-\mathrm{Mg}-\mathrm{Cu}-\mathrm{Ni}$ phase diagram in the region of compositions of high strength nickalines. Russian Journal of Non-Ferrous Metals. 2010; 51(3):243-249. http://dx.doi.org/10.3103/S1067821210030090.

19. Moore DM and Morris LR. A new superplastic aluminium sheet alloy. Materials Science and Engineering. 1980; 43(1):85-92. http://dx.doi.org/10.1016/0025-5416(80)90211-6.
20. Swaminathan K and Padmanabhan KA. Tensile flow and fracture behaviour of a superplastic Al-Ca-Zn alloy. Journal of Materials Science. 1990; 25(11):4579-4586. http://dx.doi. org/10.1007/BF01129909.

21. Aljarrah M, Medraj M, Wang X, Essadiqi E, Muntasar A and Denes G. Experimental investigation of the Mg-Al-Ca system. Journal of Alloys and Compounds. 2007; 436(1-2):131-141. http://dx.doi.org/10.1016/j.jallcom.2006.07.034.

22. Kono N, Tsuchida Y, Muromachi S and Watanabe H. Study of the Al-Ca-Zn ternary phase diagram. Light Metals. 1985; 35(10):574-580.

23. Prince A. The Al-Ca-Zn system. Bulletin of Alloy Phase Diagrams. 1989; 10(5):540-545. http://dx.doi.org/10.1007/ BF02882412.

24. Backerud L. Solidification characteristics of aluminium alloys: wrought alloys. Schaumburg: American Foundry Society; 1986. v. 1 .

25. Backerud L, Chai G and Tamminen J. Solidification characteristics of aluminium alloys: foundry alloys. Schaumburg: American Foundry Society; 1990. v. 2.

26. Saunders N and Miodownik AP. CALPHAD (calculation of phase diagrams): a comprehensive guide. Oxford: Pergamon Press; 1998.

27. Thermo-Calc Software [Internet]. Stockholm: Thermo-Calc Software; 2015 [cited 2015 Sept 11]. Available from: www. thermocalc.com 